\title{
MĚŘENÍ HLUKU PŘI PRŮTOKU DEŠŤOVÉ VODY TĚLESEM STŘEŠNÍHO VTOKU
}

\author{
MEASUREMENT OF NOISE DURING RAINWATER FLOW THROUGH \\ THE ROOF DRAIN BODY
}

David Fučík ${ }^{*}, 1$, Jan Ručka ${ }^{1}$

"fucik.d@fce.vutbr.cz

${ }^{1}$ Vysoké učení technické v Brně, Fakulta stavební, Ústav vodního hospodářství obcí, Veveří 331/95, 60200 Brno

\begin{abstract}
Abstrakt
Článek pojednává o problematice měření průtoku a hluku, který vzniká v okolí podtlakového systému odvodnění při odtoku deštové vody z úrovně střešní plochy. Dešt'ová voda je z úrovně střechy odváděna střešními vtoky, které jsou osazeny do svislých prostupů ve střešní konstrukci. V článku je popsána základní problematika měření průtoku a hluku, která se odkazuje na technické normy a další odbornou literaturu. Podle daných požadavků bude probíhat měření parametrů několika podtlakových stř̌šních vtoků od různých výrobců. Následně bude provedeno porovnání a zhodnocení naměřených dat.
\end{abstract}

\section{Klíčová slova}

Zdroj hluku, měření hluku, měření průtoku, podtlakový systém odvodnění, stř̌ešní vtok

\begin{abstract}
The article deals with the issue of measuring the flow and noise that arises in the vicinity of the siphonic drainage system during the outflow of rainwater from the roof surface. Rainwater is drained from the roof level through roof drains, which are fitted into vertical penetrations in the roof structure. The article describes the basic issues of flow and noise measurement, which refers to technical standards and other literature. According to the given requirements, the parameters of several siphonic roof drains from various manufacturers will be measured. Subsequently, the measured data will be compared and evaluated.
\end{abstract}

Key words

Noise source, measurement of noise, measurement of flow, siphonic drainage system, roof drain

\section{1 ÚVOD}

Článek pojednává o metodice měření průtoku, který jsou schopné převést podtlakové stř̌ešní vtoky, a dále o měření hluku, který vzniká nad úrovní podtlakového strešního vtoku, pod jeho úrovní i v okolí potrubní trasy celého odvodňovacího systému. Zdroj zvuku vzniká v důsledku průtoku dešt'ové vody tělesem střešního vtoku a prouděním vody v navazujícím odtokovém potrubí. V článku je popsána základní problematika měření průtoku a hluku.

Autorský kolektiv se zabývá vytvořením prakticky použitelného metodického postupu pro měření průtoku a hluku, který bude reflektovat technickými normami a také další relevantní literaturou. Podle vytvořené metodiky měření bude probíhat testování konkurenčních podtlakových stř̌šních vtoků od několika výrobců. Měření bude probíhat na sestaveném hydraulickém měřicím okruhu. Po samotném měření bude provedeno porovnání a zhodnocení naměrených dat.

\section{POPIS PODTLAKOVÉHO SYSTÉMU}

Řešené téma se zabývá problematikou podtlakového systému odvodnění plochých střech, který je v současné době při navrhování odvodnění plochých střech preferován $\mathrm{v}$ porovnání se standardním gravitačním systémem. Důvodem jsou některé jeho výhody, které spočívají zejména v menším počtu potřebných odvodňovacích prvků, které jsou ve střešní konstrukci umístěny, a nižších pořizovacích nákladech [1]. 
Pro vytvoření podtlakového efektu v podtlakovém systému, tj. po celé trase odtokového potrubí, je potřeba do střešního pláště osadit speciální střešní vtok, díky kterému může podtlakový efekt vzniknout. Jedná se o relativně sofistikovaný výrobek, jehož různé modifikace v současné době nabízí na trhu několik různých výrobců. Požadované vlastnosti střešního vtoku a jeho parametry ovlivňuje mimo jiné také tvarové řešení jeho jednotlivých částí. Na řešení střešních vtoků je proto kladen poměrně velký důraz. Nesprávně navržený stř̌ešní vtok může vykazovat např. nedostatečnou hydraulickou kapacitu, tendenci k ucpávání, nebo právě vysokou míru hluku, který vzniká při průtoku dešt'ové vody.

Při výstavbě se střešní vtoky osazují do předem vytvořených svislých prostupů, které jsou připravené ve střešní konstrukci. Střešní vtoky jsou osazeny tak, aby odváděly dešt’ové vody z úrovně střechy. Vodotěsnost střechy je zajištěna hlavní hydroizolační vrstvou, tj. hydroizolační fólií, která musí být umístěna na celé odvodňované ploše střechy. $\mathrm{V}$ místech střešních vtoků musí být provedeno hydroizolační svaření mezi fólií na hlavní hydroizolační vrstvou a manžetou, která bývá obvykle součástí stř̌ešního vtoku.

Každý střešní vtok primárního odvodnění je dále napojený na odtokové potrubí, které bývá vedeno pod střešní konstrukcí až po svislé potrubí, které bývá umístěno u svislé stěny objektu. Svislé odtokové potrubí následně ústí do stokové sítě, případně do nádrže nebo zasakovacího objektu. Jednotlivé části podtlakového systému jsou patrné z Obr. 1 .

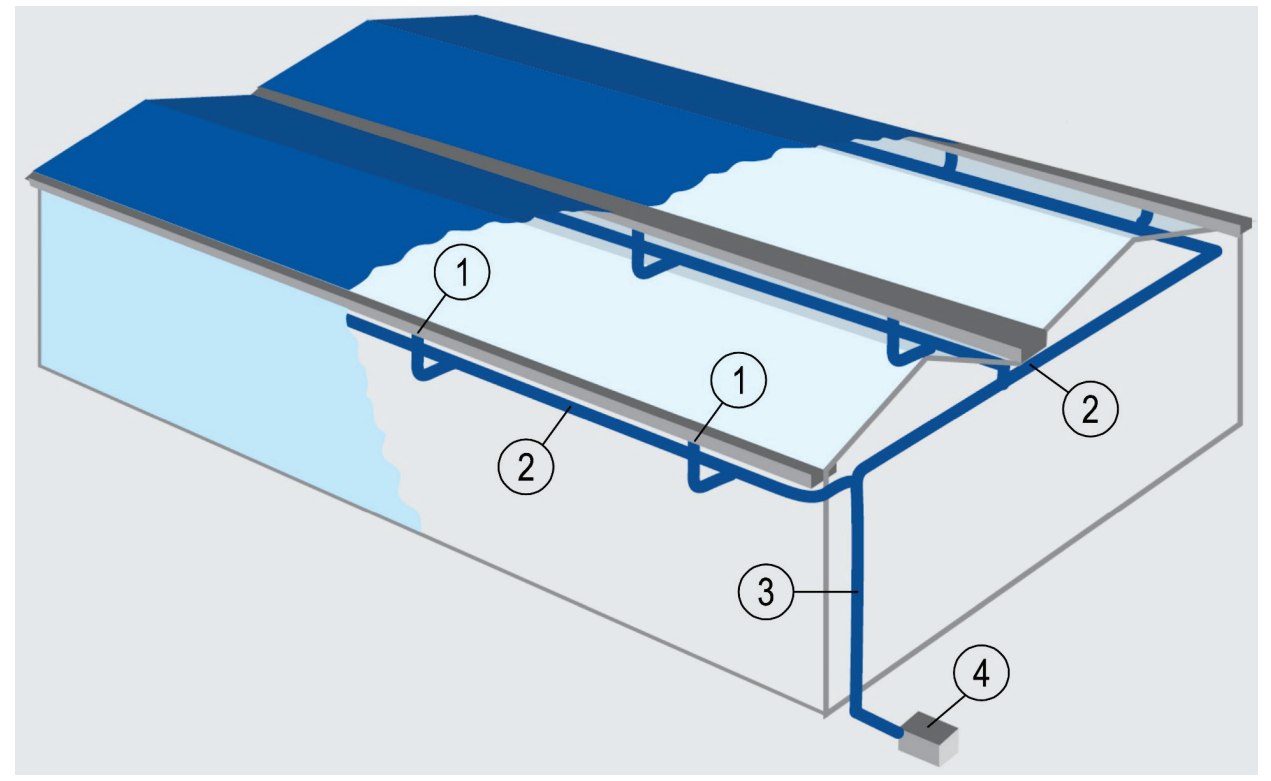

Obr. 1 Schéma podtlakového systému; 1 - podtlakový stř̌šní vtok, 2 - horizontální odtokové potrubí, 3 - svislé odtokové potrubí, 4 - vyústění z objektu [2].

Pro podtlakový systém odvodnění je žádoucí, aby se v potrubní trase vytvořil podtlakový režim proudění, tedy sací efekt, díky čemuž dochází ke zvýšení hydraulické kapacity odvodňovacího systému. Podtlakový režim vzniká teprve po dosažení a překročení určité, pro jednotlivé vtoky přesně definované, výšky zaplavení stř̌ešních vtoků.

Díky vyšší hydraulické kapacitě podtlakových systémů odvodnění je možno snížit počet potřebných střešních vtoků v porovnání s gravitačními systémy. S tím souvisí i nižší počet svislých prostupů ve střešní konstrukci, čímž se značně snižuje riziko zatečení do střešní konstrukce, příp. do samotné stavby.

\section{METODIKA MĚ̌̌ENÍ}

\section{Měření průtoku}

Měření průtoku je prováděno v návaznosti na ČSN EN 1253-2 Podlahové vpusti a střešní vtoky - Část 2: Střešní vtoky a podlahové vpusti bez zápachové uzávěrky (2016). Norma definuje podobu laboratorního měřícího okruhu a podmínky měření [3]. 
Schéma měřícího okruhu je patrné z Obr. 2, na kterém jsou očíslovány jednotlivé části měřícího okruhu. Měřící okruh je sestaven ze zásobní nádrže čtvercového tvaru s délkou strany nejméně $1,75 \mathrm{~m}$. Zásobní nádrž musí být umístěna v takové výšce, aby byla dodržena minimální spádová výška svislého potrubí, která činí 4,2 m. Podtlakový střešní vtok musí být osazený v ose zásobní nádrže, aby proudění bylo směrem ke vtoku souměrné a aby proudění nebylo ovlivněno boční stěnou nádrže. Dle technické normy může být zkouška provedena s deskou simulující plochu střechy (deska je v zásobní nádrži umístěna v horní úrovni těla střešního vtoku) nebo bez ní. Nad deskou simulující plochu střechy, resp. nad střešním vtokem musí být umístěno zařízení pro měření výšky vzdutí vody s tolerancí $\pm 2 \mathrm{~mm}$. Z důvodu snížení hladiny v okolí vtoku probíhá měření výšky vzdutí vody ve vzdálenosti $500 \mathrm{~mm}$ od svislé osy vtoku. Tolerance vzdálenosti pro měření výšky vzdutí vody je $\pm 5 \mathrm{~mm}$ [3].

Norma definuje průtok podtlakovým vtokem při výšce vzdutí $55 \mathrm{~mm}$, pro vtok o dimenzi $75 \mathrm{~mm}$ musí být jeho hodnota minimálně $121 \cdot \mathrm{s}^{-1}$. Pro vykreslení odtokové křivky, a také pro ověření minimální hodnoty průtoku, jsou určeny výšky vzdutí vody, při kterých bude probíhat měření hydraulické kapacity střešního vtoku. Hodnoty jsou $5 \mathrm{~mm}, 15 \mathrm{~mm}, 25 \mathrm{~mm}, 35 \mathrm{~mm}, 45 \mathrm{~mm}, 55 \mathrm{~mm}, 65 \mathrm{~mm}$ a $75 \mathrm{~mm}$ [4]. Odečet hodnot průtoku bude proveden po ustálení v každé z předem definovaných výšek hladiny vody nad střešním vtokem. Odečet hodnot bude spuštěn 5 minut od ustálení výšky vzdutí vody a bude probíhat 10 minut.

\section{Měření hluku}

Hlukem se rozumí zvuk, který může být škodlivý pro zdraví a jehož imisní hygienický limit stanovuje prováděcí právní předpis [5].

Osoby odpovědné za vznikající hluk jsou povinni technickými, organizačními a dalšími opatřeními zajistit, aby hluk nepřekračoval hygienické limity upravené prováděcím právním předpisem pro chráněný venkovní prostor, chráněné vnitřní prostory staveb a chráněné venkovní prostory staveb [5].

Každá metoda popisu, měření a hodnocení hluku v životním prostředí je uvažována tak, aby se nějakým způsobem vztahovala k tomu, co je známo o odezvě člověka na hluk. Mnoho škodlivých účinků hluku v životním prostředí se zvyšuje se zvyšujícím se hlukem, avšak přesné vztahy dávka-odezva zůstávají předmětem diskuze. Dále je důležité, že všechny použité metody musí být prakticky použitelné v rámci sociálního, ekonomického a politického prostředí, v němž jsou užívány. Ve světě je proto používáno mnoho různých metod pro různé typy hluku, což vytváří značné obtíže pro mezinárodní porovnání a pochopení [6].

Norma CSN EN 14366+A1: Laboratorní měření hluku z instalací odpadních vod (2020) definuje metody měření hluku šírícího se vzduchem i konstrukcemi v instalacích pro odpadní a dešt’ovou vodu v laboratorních podmínkách. Naměřená data pak mohou sloužit pro porovnání výrobků a materiálů [7].

Norma je použitelná pro soustavy potrubí pro odpadní vody a jeho části. Používá se pro potrubí vyrobené z jakéhokoliv běžného materiálu v průměrech až do $150 \mathrm{~mm}$. Norma také definuje požadavky na hydraulické zařizení, to musí být schopné dosáhnout průtoku vody minimálně $0,51 \cdot \mathrm{s}^{-1}$ a musí být schopné měřit průtok vody s presností $5 \%$ [7].

Hluk z instalací odpadních vod je vytvářen prouděním vody a spádem vody v potrubním systému. V budovách existuje mnoho různých způsobů instalace těchto systémů. Rozvody pro odpadní vody mohou být pevně zabudované např. do zdí, mohou být upevněny úchytkami ve zdech a zakryté deskami nebo mohou volně viset v prostoru nad zavěšeným podhledem. Z toho důvodu je nutné stanovit správné měřící metody pro šíření zvuku [7].

Významné zdroje hluku vznikají u ohybů svislých rozvodů, u nespojitostí, jako například spojky a přechodky. Účinek hluku je také silně závislý na vlastnostech materiálu užitého pro potrubí, na způsobu spojování a upevňování potrubí a také na obecných poměrech v místě stavby [7].

Normy, které se zabývají problematikou akustiky definují požadavky na měření hluku, konkrétně pak na zkušební zařízení. Mezi základní z nich patří následující. Objem zkušební místnosti by měl být 30 až $50 \mathrm{~m}^{3}$, výška zkušební místnosti by měla být $3 \pm 0,5 \mathrm{~m}$, dvě protější stěny by od sebe měly být vzdáleny min. $2,3 \mathrm{~m}$, při měření musí být obsluha min. $0,5 \mathrm{~m}$ za mikrofonem. Při měření ve vnitřním prostoru se doporučuje provádět měření ve výšce $1,2 \pm 0,1$ nebo $1,5 \pm 0,1 \mathrm{~m}$ od podlahy [7], [8], [9].

Na Obr. 2 jsou, mimo označení částí měřícího okruhu, označeny také hlavní zdroje hluku, které budou vznikat při měření. Jednotlivé zdroje hluku jsou označeny písmeny A-F, kde A značí hluk, který vzniká v dolní nádrži důsledkem vyústění vody z odtokového potrubí do volné hladiny v nádrži. Hluk s označením B vzniká v důsledku chodu čerpadla, které tlačí vodu do hodní nádrže, s čímž souvisí hluk $\mathrm{C}$, ten vzniká ve výtlačné větvi v návaznosti na proudění vody v potrubí. Okolní hluk je označený písmenem D. Zdroje hluku s označením E a F jsou sledované zdroje hluku. První z nich je hluk vznikající nad střešním vtokem, a to v důsledkem odtoku vody tělesem střešního vtoku. Další zdroj hluku vzniká v okolí svislého potrubí, kterým proudí voda s určitou rychlostí. 


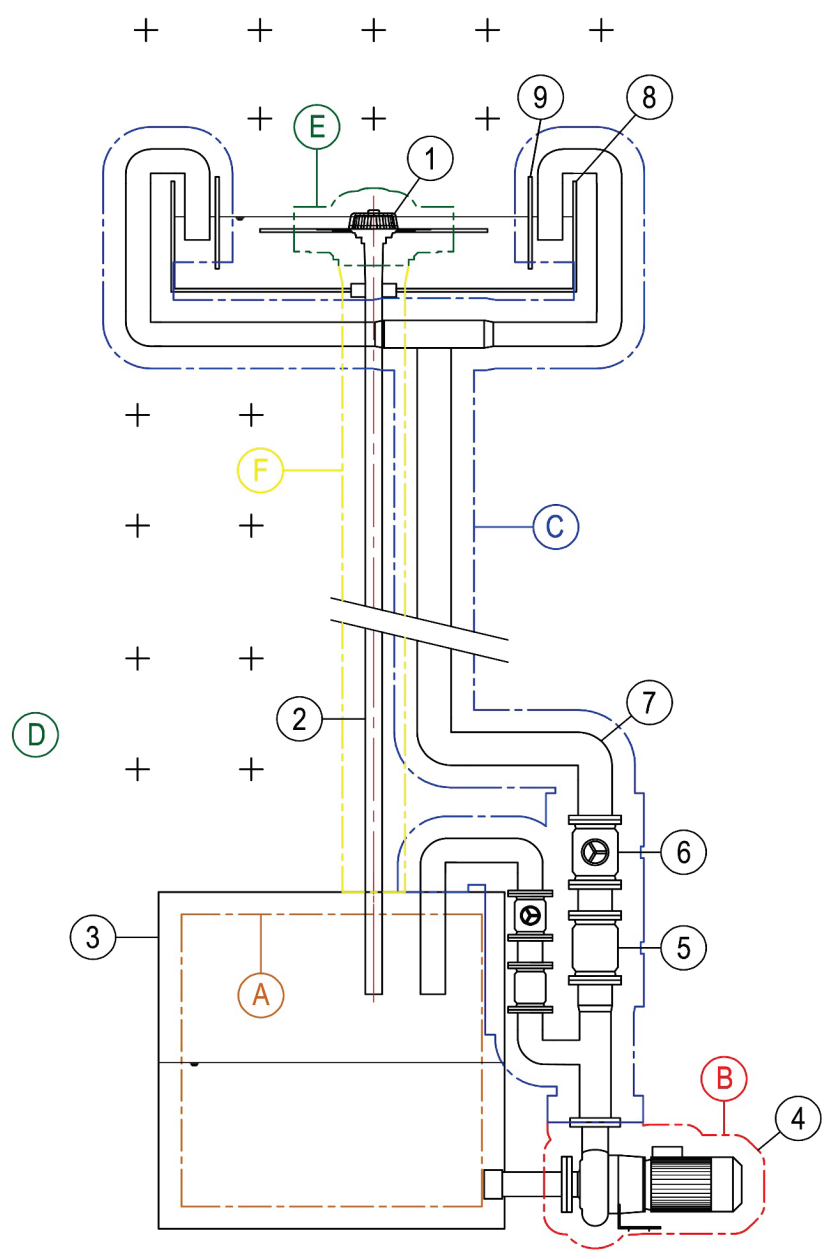

Obr. 2 Schéma měřícího zařízení s vyznačením zdrojů hluku; 1 - podtlakový střešní vtok, 2 - svislé odtokové potrubí, 3 - dolní nádrž, 4 - čerpadlo, 5 - průtokoměr, 6 - regulační armatura, 7 - výtlačné potrubí, 8 - horní nádrž, 9 - norná stěna; A - vyústění do dolní nádrže, B - chod čerpadla, C - proudění vody ve výtlačném potrubí, D - okolní hluk, E - odtok vody, F - proudění vody v odtokovém potrubí.

\section{Technické požadavky při měření hluku hlukoměry}

$\mathrm{K}$ měření hluku $\mathrm{v}$ komunálním prostředí se používají měřicí př́istroje třídy 1 , které vyhovují požadavkům ČSN EN 61672-1 Elektroakustika - Zvukoměry - Část 1: Technické požadavky. Měřicí zvukoměry tř. 1 jsou zařazeny ve vyhlášce č. 345/2002 Sb. jako stanovená měřidla, která podle zákona č. 505/1990 Sb. Podléhají úřednímu ověření stanoveného měřidla. Všechna stanovená měřidla používaná $\mathrm{k}$ měření hluku v mimopracovním prostředí musí být vybavena platným ověřovacím listem [8].

Základní určující ukazatelé hluku se vyjadřují jako hladiny akustického tlaku v decibelech při použití váhové funkce A nebo C a dynamické charakteristiky Fast (Rychle), v prŕípadě vysoce impulsního hluku i dynamické charakteristiky Impuls a Slow (Pomalu) [8].

Provozní kalibrace zvukoměrné techniky se provádí akustickými kalibrátory, které vyhovují požadavkům ČSN EN 60942 Elektroakustika - Akustické kalibrátory. Kalibraci se provádí vždy bezprostředně před začátkem a po ukončení měření, případně i v jeho průběhu. Po ukončení měření se nesmí změřená hladina akustického tlaku kalibračního signálu lišit od původně změřené hodnoty o více než $0,5 \mathrm{~dB}$. Pokud je odchylka větší, je nutné provést nové nastavení všech přístrojů a nové měření [8]. 


\section{Postup měření hluku}

Pro měření se může použít mikrofon upevněný na stativu a propojený kabelem s měřicím přístrojem nebo mikrofon upevněný spolu s měřicím prrístrojem na stativu, v takovém prrípadě musí být obsluha při měření nejméně $0,5 \mathrm{~m}$ za mikrofonem. Při měření směřuje osa hlavní citlivosti mikrofonu směrem ke zdroji hluku. Pro měření se použivá typ mikrofonu podle druhu zvukového pole nebo přístroj umožňující korekci na druh zvukového pole. Během vlastního měření obsluha měřicího přístroje bud' osobně průběžně sleduje a zaznamenává akustickou situaci nebo jsou v průběhu měření automaticky zaznamenávány údaje jako např. audiozáznam nebo videozáznam, na základě kterých mohou být při následném zpracování spolehlivě vyloučeny rušivé události a okolnosti, které by mohly negativně ovlivnit výsledek měření [10].

Př́mé měření ekvivalentní hladiny akustického tlaku $L_{\text {AeqT }}$ se preferuje v případě, že je hluk přibližně ustálený nebo časově proměnný. Př́kladem takového hluku může být např, hluk z výrobních provozů nebo hluk silniční dopravy. Aby byl daný vzorek měření reprezentativní, doporučuje se měřit minimálně 5 až 10 minut [10].

Stanovení maximální hladiny akustického tlaku $L_{\text {Amax }}$ se stanoví odečtením hodnoty $L_{\text {Amax }}$ při vyhodnocení naměřených dat, které jsou uloženy v paměti zvukoměru (postprocesing) [10].

Pro měření zbytkového hluku platí analogická pravidla a postupy jako pro měření hluku posuzovaného zdroje. Zbytkový hluk může měřit před, nebo po, případně i v průběhu měření hluku. Pro adekvátnost naměřených hodnot se doporučuje měřit na stejných místech a ve stejných veličinách jako měřený hluk včetně nejistoty měření (s výjimkou impulsního hluku, resp. $L_{\mathrm{Amax}}$ ) [10].

Korekce $K$ na zbytkový hluk se stanovuje výpočtem nebo podle tabulky v návaznosti na hodnotu $\Delta L$, která odpovídá rozdílu mezi hladinou akustického tlaku měřeného zdroje hluku a hladinou akustického tlaku zbytkového hluku [10].

Při stanovení hodnoty $\Delta L$ se neuvažuje nejistota je-li:

- $\Delta \mathrm{L}>10 \mathrm{~dB}$ : nekoriguje se,

- $\quad \Delta \mathrm{L}<3 \mathrm{~dB}(\mathrm{tj} . \mathrm{K}>3 \mathrm{~dB})$ : korekce na zbytkový hluk nejsou dovolené z toho důvodu, že hluk měřeného zdroje nelze jednoznačně odlišit od zbytkového hluku

Hodnoty korekce $K$ jsou uvedeny v Tab. 1. Výsledná korekce se odečítá od změřené hladiny akustického tlaku zdroje hluku [10].

Tab. 1 Určení hodnoty korekce na zbytkový hluk $K$ v návaznosti na rozdíl hladin akustického tlaku měřeného zdroje hluku a akustického tlaku zbytkového hluku [10].

\begin{tabular}{|c|c|c|c|c|c|c|c|c|c|c|c|c|c|c|c|}
\hline \multicolumn{16}{|c|}{ Hodnoty $\Delta L$ a $K$ uváděné v dB } \\
\hline$\Delta \mathrm{L}[\mathrm{dB}]$ & 10,0 & 9,5 & 9,0 & 8,5 & 8,0 & 7,5 & 7,0 & 6,5 & 6,0 & 5,5 & 5,0 & 4,5 & 4,0 & 3,5 & 3,0 \\
\hline $\mathrm{K}[\mathrm{dB}]$ & 0,5 & 0,5 & 0,6 & 0,7 & 0,7 & 0,9 & 1,0 & 1,1 & 1,3 & 1,4 & 1,7 & 1,9 & 2,2 & 2,6 & 3,0 \\
\hline
\end{tabular}

Měření míry hluku bude probíhat v několika měřících bodech, které jsou znázorněny na Obr. 2. Každý měřící bod je znázorněný symbolem křŕžku. Ty jsou patrné nad stř̌šním vtokem a na levé straně obrázku. Vzdálenosti měřících bodů od zdroje hluku a dále od sousedních měřících bodů odpovídá hodnotě $0,5 \mathrm{~m}$.

\section{Neakustické údaje}

Při měření hluku se na měřeném místě zjišt’ují kromě údajů o hluku také údaje a veličiny neakustické. Mezi tyto údaje patří např. topografické situování místa vzhledem k zdroji hluku, možnost šíření hluku od zdroje do místa měření, fyzikální a atmosférické podmínky při měření, popis a charakteristika zdroje hluku, doba trvání hluku a všechny další okolnosti, které by mohly ovlivnit průběh a výsledek měření. Tyto údaje je nutné uvést do protokolu z měření [8].

\section{ZÁVĚR}

Článek řeší základní problematiku měření hydraulické kapacity podtlakových střešních vtoků a s ní související problematiku měření hluku, který vzniká nad úrovní podtlakového střešního vtoku, pod jeho úrovní, resp. pod úrovní stř̌ešní konstrukce a dále pak i v okolí celé odvodňovací trasy potrubí, které bývá vedeno vodorovně pod stropem a svisle po stěně dotčené stavby. Zdroj zvuku vzniká v návaznosti na odtok dešt'ové vody tělesem střešního vtoku a prouděním vody v odtokovém potrubí. Článek dále popisuje metodiku měření, která specifikuje požadavky měření s odkazem na technické normy a další literaturu. 
V návaznosti na vytvořenou metodiku měření bude probíhat testování několika podtlakových střešních vtoků od různých výrobců. Měření bude probíhat na sestaveném hydraulickém měřicím okruhu. Po samotném měření bude provedeno porovnání a zhodnocení naměřených dat. Výsledky zhodnocení budou dále použity pro vytvoření nového tvaru podtlakového střešního vtoku, který bude optimální z hlediska proudění dešt'ové vody tělesem vtoku, což povede ke snížení hodnoty vznikajícího hluku.

\section{Poděkování}

Práce byla financována $\mathrm{z}$ rozpočtu projektu „Řešení vybraných problémů ve vodním hospodářství obcí“, registrační číslo FAST-J-21-7477, který je financován z programu Specifického vysokoškolského výzkumu Vysokého učení technického v Brně.

\section{Použité zdroje}

[1] FUČÍK, David a Jan RUČKA. Review of Siphonic Roof Drainage Systems. MM Science Journal, 2019, 3683 - 3689. ISSN: 1805-0476.

[2] Terrain Hydromax: Siphonic roof drainage system [online]. Terrain, 2019 [cit. 2021-11-24]. Dostupné z: https://www.polypipe.com/sites/default/files/srds3_siphonic_roof_drainage_jan19_0.pdf

[3] ČSN EN 1253-2: Podlahové vpusti a střešní vtoky - Část 2: Střešní vtoky a podlahové vpusti bez zápachové uzávěrky. ICS 91.140.80. Praha: Úřad pro technickou normalizaci, metrologii a státní zkušebnictví, 2016.

[4] FUČÍK, David a Jan RUČKA. Změna odtoku vody v závislosti na tvaru podtlakového vtoku. In: Juniorstav 2021: Sborník př́íspěvků. 23. odborná konference doktorského studia. Brno: Vysoké učení technické v Brně, Fakulta stavební, 2021, 451 - 456. ISBN 978-80-86433-75-2.

[5] ČESKÁ REPUBLIKA. Zákon č. 258/2000 Sb.: Zákon o ochraně veřejného zdraví a o změně některých souvisejících zákonů. In: . 2000. Dostupné také z: https:/www.zakonyprolidi.cz/cs/2000-258/zneni20210427

[6] ČSN ISO 1996-1: Akustika - Popis, měření a hodnocení hluku prostředí - Část 1: Základní veličiny a prostupy pro hodnocení. ICS 13.140. Praha: Úřad pro technickou normalizaci, metrologii a státní zkušebnictví, 2017.

[7] ČSN EN 14366+A1: Laboratorní měření hluku z instalací odpadních vod. ICS 17.140.20. Česká agentura pro standardizaci, 2020.

[8] Věstník Ministerstva zdravotnictví České republiky. In: . Praha, 2017, částka 11. Dostupné také z: https:/www.mzcr.cz/wpcontent/uploads/wepub/14382/36099/V\%C4\%9Bstn\%C3\%ADk\%20MZ\%20\%C4\%8CR\%20112017.pdf

[9] ČSN EN ISO 3822-1: Akustika - Laboratorní zkoušky emise hluku armatur a zařízení vnitřních vodovodů - Část 1: Metody měření. ICS 17.140.20. Český normalizační institut, 2000.

[10] ČSN ISO 1996-2: Akustika - Popis, měření a hodnocení hluku prostředí - Č́st 2: Určování hladin akustického tlaku. ICS 17.140.01. Česká agentura pro standardizaci, 2018. 